\title{
Deflouridation from Aqueous Solutions Using Alum
}

\author{
V. SUBHASHINI ${ }^{\mathrm{a}^{*}}$, A. V. V. S. SWAMY ${ }^{\mathrm{a}}$ and R. HEMA KRISHNA ${ }^{\mathrm{b}}$ \\ ${ }^{a}$ Department of Environmental Sciences, Acharya Nagarjuna University, \\ Nagarjuna Nager-522510, Guntur (Dist.) Andhra Pradesh, India \\ ${ }^{\mathrm{b}}$ Department of Chemistry, University of Toronto, Ontario, M3J 1P3, Canada. \\ hkravuri32@gmail.com
}

Received 26 May 2012 / Accepted 14 June 2012

\begin{abstract}
This research work has been designed to remove the fluoride from aqueous solutions using alum by bench scale experiments. The defluoridating agent, which is easily available even in rural areas, has been selected. The known concentrations of fluoride solution were prepared. The removal of fluorides by the defluoridating agent was studied up to 4 hours for all the fluoride concentrations. The variations in the percentage removal and attainment of equilibrium were recorded. The solutions of 2 , 4, 6, 8 and $10 \mathrm{mg} / \mathrm{L}$ were prepared. Each Fluoride concentration was tested with 100, 200 and $300 \mathrm{mg} / \mathrm{L}$ of alum. The removal of fluoride increased at the rate of $10 \%$ per hour up to $55 \%$ by $4 \mathrm{~h}$ for 100 and $200 \mathrm{mg} / \mathrm{L}$ while it rose from 40 to $60 \%$ by $4 \mathrm{~h}$ equilibration time in $300 \mathrm{mg} / \mathrm{L}$ alum solution it reaches $60 \%$. The difference of fluoride removal between 100 and $300 \mathrm{mg} / \mathrm{L}$ alum concentrations was only $5 \%$ i.e. 0.9 and $0.8 \mathrm{mg} / \mathrm{L}$ of fluoride remained after $4 \mathrm{~h}$ equilibration time. All the concentrations of defluoridating agent have successfully reduced the fluoride content in waters to permissible limits.
\end{abstract}

Keywords: Deflouridation, Alum, Aqueous solutions, Equilibrium time, Batch tests

\section{Introduction}

Fluoride exists in many forms and the harmful nature of the fluoride is contingent upon the type of fluoride it is. Depending on its concentration, the fluoride in drinking water is known for both beneficial and detrimental effects on health, particularly to infants and young children. Fluoride is perhaps the only element whose deficiency $(<0.5 \mathrm{ppm})$ as well as its presence in excess $(>1.5 \mathrm{ppm})$ in drinking water has serious health implications. It is well known for its adverse health effects. It acts as an essential element up to $1.0 \mathrm{mg} / \mathrm{L}$ helping in teeth formation and strengthening of skeleton, beyond the limit it exerts negative impacts on the human health causing debilitating disease named "Fluorosis".

The optimum fluoride level in drinking water for general good health set by WHO is considered to be between 0.5 and $1.0 \mathrm{mg} / \mathrm{L}^{1-3}$. Fluoride concentrations in groundwater of some places in the world exceed the acceptable value; for example, in some area of Northeast China the fluoride concentration is about $4 \mathrm{mg} / \mathrm{L}$. Fluoride removal from drinking water is presently a common practice worldwide. 
To date, various methods to remove fluoride from groundwater have been proposed and applied in decades. Sedimentation with calcium and aluminum salts is one of the commonly used processes to eliminate fluoride. It can reduce the fluoride concentration to about $2 \mathrm{mg} / \mathrm{L}$ and can be used for fluoride-rich industrial wastewater treatment as well ${ }^{4}$. However, the process generates large amounts of fluoride-containing sludge and causes an unavoidable sludge treatment and disposal problem with increased costs 5 . Other methods, which include ion exchange, membrane (including reverse osmosis and nano-filtration), Donnan dialysis and integrated physiochemical and biological adsorption on active alumina, fly ash and carbon nano-tubbe etc., have all been used for fluoride removal practice ${ }^{6-12}$. Among the various methods, it has been accepted that the ion exchange electro-dialysis and membrane processes are effective and can remove the fluoride to a suitable level. But they are expensive and require frequent regeneration of ion exchange beds or cleaning of the scaling and fouling on the membrane $e^{5}$. Although adsorption of defluoridation from drinking water by activated alumina was successfully demonstrated, the fluoride removal capacity changed significantly with $\mathrm{pH}$ value of water. In addition, it was found that the $\mathrm{Al}^{3+}$ ions released during the treatment process. Therefore, searching for cost-effective adsorbents remains an active theme in the research and practice of fluoride removal. In recent years, a lot of efforts have been devoted and some new cost-effective fluoride adsorbents, such as, zeolites and biomass material, like fishbone charcoal ${ }^{13-14}$ as well as other novel adsorbents ${ }^{15}$ have been identified and investigated.

The present work was initiated to find out an easy and practicable solution to the problem, more specifically with the following objectives (1) To remove fluorides from drinking water that contains $2,4,6,8$ and $10 \mathrm{mg} / \mathrm{L}$. (2) To study the defluoridating efficiency of alum and test the performance of this defluoridating agent at different concentrations viz.100, 200 and $300 \mathrm{mg} / \mathrm{L}$. (3) To make defluoridation process user-friendly by avoiding complicated processes generally undertaken on bench scale experiments that are not practicable to the households.

\section{Experimental}

Alum was used to remove the fluorides from the drinking water. The concentrations of fluorides selected for removal from freshwater were $2,4,6,8$ and $10 \mathrm{ppm}$, that correspond to the levels of fluorides available in the natural waters of the fluoride infested areas in Guntur and Nalgonda districts of Andhra Pradesh. However, for the present study the distilled water was used to prepare the test solutions. The distilled water that was used for removal of fluorides did not contain more than $0.3 \mathrm{ppm}$ and for every experiment a blank was also prepared.

The alum $\left(\left(\mathrm{Al}_{2} \mathrm{SO}_{4}\right)_{3} 18 . \mathrm{H}_{2} \mathrm{O}\right)$ used for the experiments have been purchased in the commercially available form. For ascertaining consistency AR grade alum and other chemicals were used. Alum was administered as defluoridating agent in 100, 200 and $300 \mathrm{mg} / \mathrm{L}$ concentrations studied for the efficiency of fluoride removal. An optimum equilibration time has been identified for all the concentrations of fluorides with all the defluoridating agents. The experiment was run for all the fluoride concentrations and the quantum of fluorides removed from the respective concentrations by estimation after every 30 minutes up to $4 \mathrm{~h}$. Many earlier workers have run the experiment for 120 minutes only. Since the present study is aimed at meeting the needs of the domestic sector with no addition of chemicals, maintenance of $\mathrm{pH}$, additional contact time has been tried. In the pilot experiment from lowest to highest concentrations the removal continued to a considerable period beyond 120 minutes hence, the fluoride removal was tested up to four hours. The removal beyond $4 \mathrm{~h}$ was negligible and hence a four-hour equilibration time was adopted for all the series of experiments in the study. 
The results of the fluoride removal are expressed as milligrams per litre $(\mathrm{mg} / \mathrm{L})$. After addition of defluoridating agent to all selected concentrations, the removal was measured for every half an hour up to 4 hours. The difference between the initial and final concentrations at every interval is reported as the fluoride removed. The removal efficiency of alum, was expressed in percent removals.

\section{Estimation of fluoride concentrations}

Estimation of fluoride concentrations has been carried out by adopting the procedure described in the NEERI Manual ${ }^{16}$. The reagents prepared for analysis are of AR grade and the solutions are prepared afresh whenever necessary. The procedure followed for estimation of fluoride is briefly described in the following account.

A standard curve (Figure 1) is prepared by plotting concentration of fluoride on $\mathrm{x}$-axis and absorbance on $y$-axis with known concentrations of standard fluoride solutions of 1-15 $\mathrm{mg} / \mathrm{L}$ at intervals of $1 \mathrm{mg} / \mathrm{L}$ (i.e. $1,2,3,4,5, \ldots \ldots 15 \mathrm{mg} / \mathrm{L}$ ). Standard stock solution of fluoride was prepared by dissolving $221.0 \mathrm{mg}$ of anhydrous sodium fluoride in $1000 \mathrm{~mL}$ of distilled water to make a solution of each $\mathrm{ml}$ containing $1 \mathrm{mg}$.

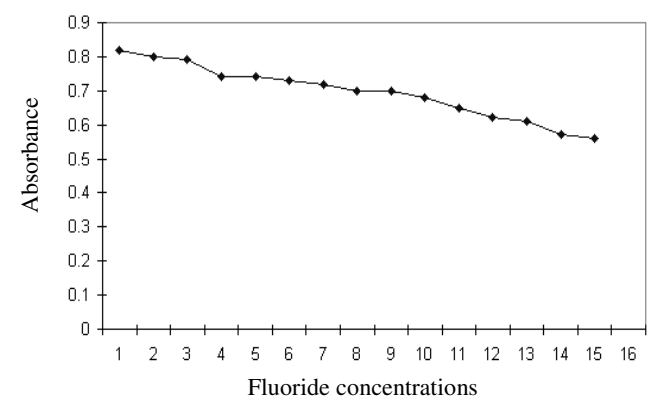

Figure 1. Calibration curve

To all the solutions containing a known concentration of fluorides, $10 \mathrm{~mL}$ of acid zyrconyl SPADNS reagent was added and the contents were mixed well and the optical density of the bleached colour was read in spectro-photometer (Elico Model No. 207/0535/II12) at $570 \mathrm{~nm}$.

The same procedure was adopted for estimation of fluorides in the samples after administration of defluoridating agents at every half an hour up to 4 hours. Basing on the absorbance, the concentrations of the fluorides in the unknown samples are read from the calibration curve. The difference between two successive estimations was taken as the fluoride removed by the respective defluoridating agent. The $\mathrm{pH}$ during the experiments ranged between 7.2 to 7.6. The present study on defluoridation is only a bench scale experiment to select appropriate concentrations of defluoridating agents that suit to the requirements of the fluoride present in natural waters of various regions.

\section{Results and Discussion}

Fluorine in drinking waters is a detrimental factor to the standard of living and hence there have been many efforts to identify ways and means to decrease its concentrations in the drinking water. In the present study, the defluoridating agent, which was easily available even in rural areas, has been selected. The selected agent was tested for their defluoridation efficiency for the fluoride concentrations that are reported from natural waters. The known concentrations of fluoride solutions were prepared as per the procedures given in the literature ${ }^{16}$. 
During the experiment, removal of fluoride at half an hour intervals was calculated as described in the methodology. The removal of fluorides by the defluoridating agent was studied up to 4 hours for all the fluoride concentrations. The variations in the percentage removal and attainment of equilibrium are recorded. The solutions of 2, 4, 6, 8 and $10 \mathrm{mg} / \mathrm{L}$ were prepared as described in the method ${ }^{16}$. Each fluoride concentration was tested with 100,200 and $300 \mathrm{mg} / \mathrm{L}$ of alum. The results of the defluoridation experiments for various concentrations are described in the following chapters.

\section{Concentrations of alum on the defluoridation of water containing $2 \mathrm{mg} / \mathrm{L}$ fluoride}

The water samples containing $2 \mathrm{mg} / \mathrm{L}$ fluoride has been treated with 100, 200 and $300 \mathrm{mg} / \mathrm{L}$ of alum concentrations. The concentration of the fluoride decreased to permissible limit within first half an hour. However, the percentage removal of fluoride was $35 \%$ for 100 and $40 \%$ for $200 \mathrm{mg} / \mathrm{L}$ of alum and the removal was $50 \%$ with $300 \mathrm{mg} / \mathrm{L}$ alum within half an hour (Table 1). The removal of fluoride increased at the rate of $10 \%$ per hour up to $55 \%$ by $4 \mathrm{~h}$ for 100 and $200 \mathrm{mg} / \mathrm{L}$ while it rose from 40 to $60 \%$ by $4 \mathrm{~h}$ equilibration time in $300 \mathrm{mg} / \mathrm{L}$ alum solution it reaches $60 \%$ shown in Figure 2. The difference of fluoride removal between 100 and $300 \mathrm{mg} / \mathrm{L}$ alum concentrations was only $5 \%$ i.e. 0.9 and $0.8 \mathrm{mg} / \mathrm{L}$ of fluoride remained after $4 \mathrm{~h}$ equilibration time. All the concentrations of defluoridating agents have successfully reduced the fluoride content in waters to permissible limits ${ }^{17}$.

Table 1. Effect of different concentrations of alum on the defluoridation of water containing $2 \mathrm{mg} / \mathrm{L}$ fluoride

\begin{tabular}{|c|c|c|c|c|c|c|c|c|c|c|}
\hline \multirow[b]{3}{*}{$\begin{array}{c}\text { S. } \\
\text { No. }\end{array}$} & \multirow{3}{*}{ 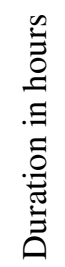 } & \multicolumn{9}{|c|}{ Alum concentration } \\
\hline & & \multicolumn{3}{|c|}{$100 \mathrm{mg} / \mathrm{L}$} & \multicolumn{3}{|c|}{$200 \mathrm{mg} / \mathrm{L}$} & \multicolumn{3}{|c|}{$300 \mathrm{mg} / \mathrm{L}$} \\
\hline & & 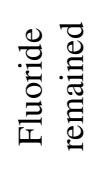 & 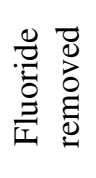 & $\begin{array}{l}\bar{\sigma} \\
2 \\
0 \\
0 \\
0 \\
0 \\
0\end{array}$ & 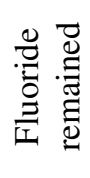 & 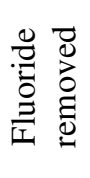 & $\begin{array}{l}\pi \\
\text { के } \\
0 \\
0 \\
0 \\
0 \\
0\end{array}$ & 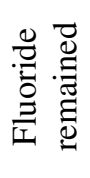 & 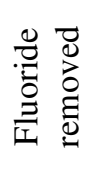 & $\begin{array}{l}\bar{\pi} \\
0 \\
0 \\
0 \\
0 \\
0 \\
0\end{array}$ \\
\hline 1 & 0.5 & 1.3 & 0.7 & 35 & 1.2 & 0.8 & 40 & 1.0 & 1.0 & 50 \\
\hline 2 & 1.0 & 1.2 & 0.8 & 40 & 1.2 & 0.8 & 40 & 1.0 & 1.0 & 50 \\
\hline 3 & 1.5 & 1.2 & 0.8 & 40 & 1.1 & 0.9 & 45 & 0.9 & 1.1 & 55 \\
\hline 4 & 2.0 & 1.1 & 0.9 & 45 & 1.1 & 0.9 & 45 & 0.8 & 1.2 & 60 \\
\hline 5 & 2.5 & 1.1 & 0.9 & 45 & 1.0 & 1.0 & 50 & 0.8 & 1.2 & 60 \\
\hline 6 & 3.0 & 1.0 & 1.0 & 50 & 0.9 & 1.1 & 55 & 0.8 & 1.2 & 60 \\
\hline 7 & 3.5 & 0.9 & 1.1 & 55 & 0.9 & 1.1 & 55 & 0.8 & 1.2 & 60 \\
\hline 8 & 4.0 & 0.9 & 1.1 & 55 & 0.8 & 1.2 & 60 & 0.8 & 1.2 & 60 \\
\hline
\end{tabular}

Concentrations of alum on the defluoridation of water containing $4 \mathrm{mg} / \mathrm{L}$ fluoride

The alum concentrations when tried in 100,200 and $300 \mathrm{mg} / \mathrm{L}$ concentrations to remove fluoride from the waters containing $4 \mathrm{mg} / \mathrm{L}$ concentration, the experiments showed a comparatively slower rate of removal with $20,25.0$ and $27.5 \%$, respectively, by 100,200 and $300 \mathrm{mg} / \mathrm{L}$ of alum solutions (Table 2). The highest removal in $100 \mathrm{mg} / \mathrm{L}$ of alum concentration was only $55 \%$ leaving behind $1.8 \mathrm{mg} / \mathrm{L}$ of fluoride in the sample and $1.8 \mathrm{mg} / \mathrm{L}$ of fluoride was left behind with $200 \mathrm{mg} / \mathrm{L}$ defluoridating solution while with $300 \mathrm{mg} / \mathrm{L}$ of alum concentration at $3.5 \mathrm{~h}$ of equilibration time, $2.4 \mathrm{mg} / \mathrm{L}$ of fluoride was removed leaving behind a fluoride content ${ }^{18}$ of $1.6 \mathrm{mg} / \mathrm{L}$ ( $60 \%$ removal) shown in Figure 2. 
Table 2. Effect of different concentrations of alum on the defluoridation of water containing $4 \mathrm{mg} / \mathrm{L}$ fluoride

\begin{tabular}{|c|c|c|c|c|c|c|c|c|c|c|}
\hline \multirow[b]{3}{*}{$\begin{array}{l}\stackrel{\circ}{Z} \\
\dot{s}\end{array}$} & \multirow[b]{3}{*}{ 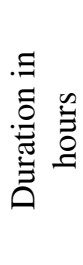 } & \multicolumn{9}{|c|}{ Alum concentration } \\
\hline & & \multicolumn{3}{|c|}{$100 \mathrm{mg} / \mathrm{L}$} & \multicolumn{3}{|c|}{$200 \mathrm{mg} / \mathrm{L}$} & \multicolumn{3}{|c|}{$300 \mathrm{mg} / \mathrm{L}$} \\
\hline & & 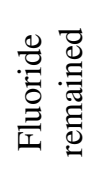 & 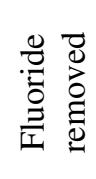 & $\begin{array}{l}\overline{7} \\
\overline{0} \\
0 \\
0 \\
0 \\
0 \\
0\end{array}$ & 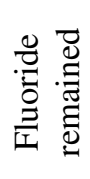 & 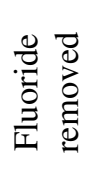 & $\begin{array}{l}\bar{\pi} \\
2 \\
0 \\
0 \\
0 \\
0 \\
0 \\
0\end{array}$ & 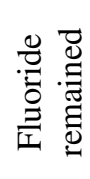 & 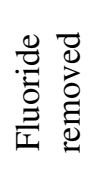 & $\begin{array}{l}\bar{\pi} \\
2 \\
0 \\
0 \\
0 \\
0 \\
0\end{array}$ \\
\hline 1 & 0.5 & 3.2 & 0.8 & 20.0 & 3.0 & 1.0 & 25.0 & 2.9 & 1.1 & 27.5 \\
\hline 2 & 1.0 & 3.1 & 0.9 & 22.5 & 2.9 & 1.1 & 27.5 & 2.3 & 1.7 & 42.5 \\
\hline 3 & 1.5 & 3.0 & 1.0 & 25.0 & 2.8 & 1.2 & 30.0 & 2.2 & 1.8 & 45.0 \\
\hline 4 & 2.0 & 2.8 & 1.2 & 30.0 & 2.6 & 1.4 & 35.0 & 2.0 & 2.0 & 50.0 \\
\hline 5 & 2.5 & 2.5 & 1.5 & 37.5 & 2.2 & 1.8 & 45.0 & 1.8 & 2.2 & 55.0 \\
\hline 6 & 3.0 & 2.0 & 2.0 & 50.0 & 1.9 & 2.1 & 52.5 & 1.6 & 2.4 & 60.0 \\
\hline 7 & 3.5 & 1.9 & 2.1 & 52.5 & 1.8 & 2.2 & 55.0 & 1.6 & 2.4 & 60.0 \\
\hline 8 & 4.0 & 1.8 & 2.2 & 55.0 & 1.8 & 2.2 & 55.0 & 1.6 & 2.4 & 60.0 \\
\hline
\end{tabular}

Concentrations of alum on the defluoridation of water containing $6 \mathrm{mg} / \mathrm{L}$ fluoride

The fluoride removal was very slow initially from the water sample containing $6 \mathrm{mg} / \mathrm{L}$ of fluoride in all the three treatment concentrations of alum. However, it increased with increasing concentration of alum (Table 3). The maximum fluoride removed was 3.4, 3.6 and 3.7 in 100, 200 and $300 \mathrm{mg} / \mathrm{L}$ concentration of alum, respectively. The fluoride content after treatment in $300 \mathrm{mg} / \mathrm{L}$ at $4 \mathrm{~h}$ equilibration time was nearer to the permissible limit. There was a sudden increase of the rate of removal of fluoride from first half an hour to first one hour viz., from 10.0 to $15 \%, 16.7$ to $26.7 \%$ and 21.7 to $30 \%$. A maximum of $61.7 \%$ was removed with $300 \mathrm{mg} / \mathrm{L}$ of alum while $60 \%$ and $56.7 \%$ fluoride was removed with 200 and $100 \mathrm{mg} / \mathrm{L}$ of alum, respectively as shown in Figure 2.

Table 3. Effect of different concentrations of alum on the defluoridation of water containing $6 \mathrm{mg} / \mathrm{L}$ fluoride

\begin{tabular}{|c|c|c|c|c|c|c|c|c|c|c|}
\hline \multirow[b]{3}{*}{$\begin{array}{l}\stackrel{0}{Z} \\
\dot{s}\end{array}$} & \multirow{3}{*}{ 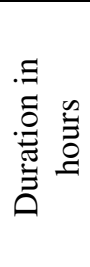 } & \multicolumn{9}{|c|}{ Alum concentration } \\
\hline & & \multicolumn{3}{|c|}{$100 \mathrm{mg} / \mathrm{L}$} & \multicolumn{3}{|c|}{$200 \mathrm{mg} / \mathrm{L}$} & \multicolumn{3}{|c|}{$300 \mathrm{mg} / \mathrm{L}$} \\
\hline & & 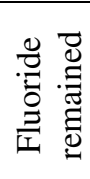 & 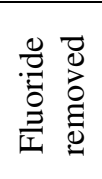 & $\begin{array}{l}\bar{a} \\
\overline{0} \\
0 \\
0 \\
0 \\
0 \\
0\end{array}$ & 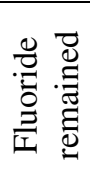 & 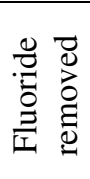 & 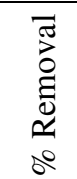 & 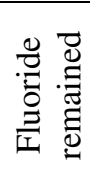 & 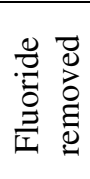 & 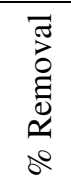 \\
\hline 1 & 0.5 & 5.4 & 0.6 & 10.0 & 5.0 & 1.0 & 16.7 & 4.7 & 1.3 & 21.7 \\
\hline 2 & 1.0 & 5.1 & 0.9 & 15.0 & 4.4 & 1.6 & 26.7 & 4.2 & 1.8 & 30.0 \\
\hline 3 & 1.5 & 4.4 & 1.6 & 26.7 & 3.6 & 2.4 & 40.0 & 3.1 & 2.9 & 48.4 \\
\hline 4 & 2.0 & 3.3 & 2.7 & 45.0 & 2.9 & 3.1 & 51.7 & 2.9 & 3.1 & 51.7 \\
\hline 5 & 2.5 & 3.1 & 2.9 & 48.3 & 2.6 & 3.4 & 56.7 & 2.7 & 3.3 & 55.0 \\
\hline 6 & 3.0 & 2.8 & 3.2 & 53.3 & 2.5 & 3.5 & 58.3 & 2.6 & 3.4 & 56.7 \\
\hline 7 & 3.5 & 2.6 & 3.4 & 56.7 & 2.4 & 3.6 & 60.0 & 2.5 & 3.5 & 58.5 \\
\hline 8 & 4.0 & 2.6 & 3.4 & 56.7 & 2.4 & 3.6 & 60.0 & 2.3 & 3.7 & 61.7 \\
\hline
\end{tabular}




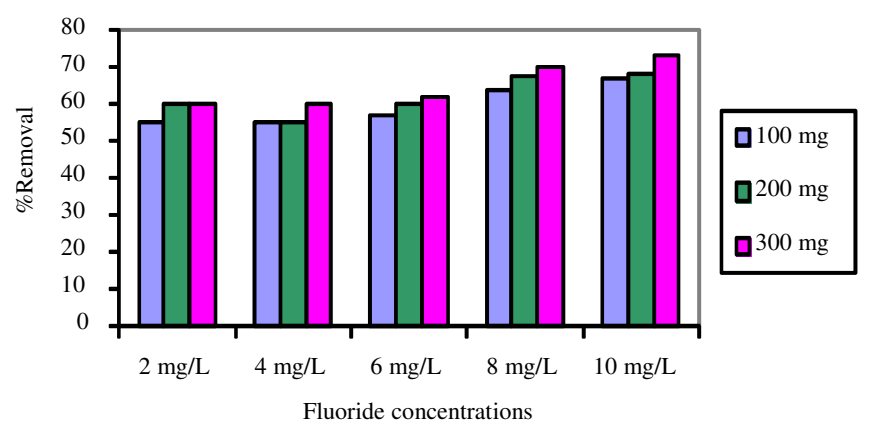

Figure 2. Graph showing the performance of alum, at 100, 200 and $300 \mathrm{mg} / \mathrm{L}$ concentrations in the defluoridation of 2, 4, 6, 8 and $10 \mathrm{mg} / \mathrm{L}$ fluoride concentrations from water

\section{Concentrations of alum on the defluoridation of water containing $8 \mathrm{mg} / \mathrm{L}$ fluoride}

The water sample containing $8 \mathrm{mg} / \mathrm{L}$ of fluoride has been subjected to defluoridation with 100 , 200 and $300 \mathrm{mg} / \mathrm{L}$ of alum for a constant period of $4 \mathrm{~h}$ equilibration time. The rate of defluoridation was slow and less with $100 \mathrm{mg} / \mathrm{L}$ of alum in the initial stages however, at the equilibration time $(4 \mathrm{~h})$ there was only a difference of $<10 \%$. There was almost double the rate of removal of fluoride in 200 and $300 \mathrm{mg} / \mathrm{L}$ of alum concentrations (Table 4). The performance of $300 \mathrm{mg} / \mathrm{L}$ of defluoridating agent at $4 \mathrm{~h}$ equilibration time was comparatively better but the left over concentrations of the fluoride was about $2.4 \mathrm{mg} / \mathrm{L}$ higher than the permissible limit ${ }^{19}$. A maximum of $70 \%$ was removed with $300 \mathrm{mg} / \mathrm{L}$ of alum while $67.5 \%$ and $63.8 \%$ fluoride was removed with 200 and $100 \mathrm{mg} / \mathrm{L}$ of alum, respectively as shown in Figure 2.

Table 4. Effect of different concentrations of alum on the defluoridation of water containing $8 \mathrm{mg} / \mathrm{L}$ fluoride

\begin{tabular}{|c|c|c|c|c|c|c|c|c|c|c|}
\hline \multirow[b]{3}{*}{$\begin{array}{l}\hat{Z} \\
\dot{v}\end{array}$} & \multirow[b]{3}{*}{ 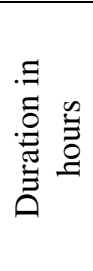 } & \multicolumn{9}{|c|}{ Alum concentration } \\
\hline & & \multicolumn{3}{|c|}{$100 \mathrm{mg} / \mathrm{L}$} & \multicolumn{3}{|c|}{$200 \mathrm{mg} / \mathrm{L}$} & \multicolumn{3}{|c|}{$300 \mathrm{mg} / \mathrm{L}$} \\
\hline & & 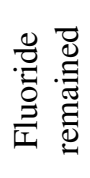 & 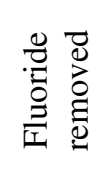 & 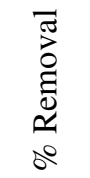 & 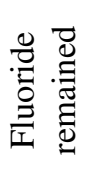 & 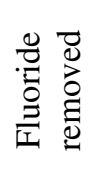 & $\begin{array}{l}\bar{\pi} \\
0 \\
0 \\
0 \\
0 \\
2 \\
0\end{array}$ & 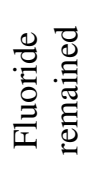 & 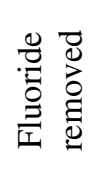 & 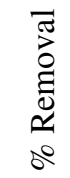 \\
\hline 1 & 0.5 & 6.7 & 1.3 & 16.30 & 5.8 & 2.2 & 27.5 & 5.2 & 2.8 & 35.0 \\
\hline 2 & 1.0 & 6.0 & 2.0 & 25.0 & 5.2 & 2.8 & 35.0 & 4.8 & 3.2 & 40.0 \\
\hline 3 & 1.5 & 5.5 & 2.5 & 31.3 & 4.7 & 3.3 & 41.3 & 4.2 & 3.8 & 47.5 \\
\hline 4 & 2.0 & 4.7 & 3.3 & 41.3 & 4.0 & 4.0 & 50.0 & 3.7 & 4.3 & 53.8 \\
\hline 5 & 2.5 & 3.4 & 4.6 & 57.5 & 3.3 & 4.7 & 58.5 & 3.0 & 5.0 & 62.5 \\
\hline 6 & 3.0 & 3.3 & 4.7 & 58.8 & 3.1 & 4.9 & 61.3 & 2.7 & 5.3 & 66.3 \\
\hline 7 & 3.5 & 3.2 & 4.8 & 60.0 & 3.0 & 5.0 & 62.5 & 2.6 & 5.4 & 67.5 \\
\hline 8 & 4.0 & 2.9 & 5.1 & 63.8 & 2.6 & 5.4 & 67.5 & 2.4 & 5.6 & 70.0 \\
\hline
\end{tabular}

Concentrations of alum on the defluoridation of water containing $10 \mathrm{mg} / \mathrm{L}$ fluoride

Defluoridation of water containing $10 \mathrm{mg} / \mathrm{L}$ of fluoride was tested with 100, 200 and $300 \mathrm{mg} / \mathrm{L}$ of alum for $4 \mathrm{~h}$ of equilibration time. Within first half an hour, 28, 34 and $41 \%$ of fluoride was removed from the water treated with 100, 200 and $300 \mathrm{mg} / \mathrm{L}$ of alum, respectively. Nearly one third of the fluoride was removed within half an hour. The removal 
increased with increasing concentration of alum (Table 5). A maximum of $73 \%$ was removed with $300 \mathrm{mg} / \mathrm{L}$ of alum while $68 \%$ and $67 \%$ fluoride was removed with 200 and $100 \mathrm{mg} / \mathrm{L}$ of alum ${ }^{20}$, respectively as shown in Figure 2.

Table 5. Effect of different concentrations of alum on the defluoridation of water containing $10 \mathrm{mg} / \mathrm{L}$ fluoride

\begin{tabular}{|c|c|c|c|c|c|c|c|c|c|c|}
\hline \multirow[b]{2}{*}{$\begin{array}{l}\stackrel{2}{z} \\
\dot{\boldsymbol{s}}\end{array}$} & \multirow[b]{2}{*}{ 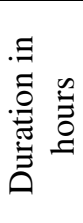 } & \multicolumn{3}{|c|}{$100 \mathrm{mg} / \mathrm{L}$} & \multicolumn{3}{|c|}{$200 \mathrm{mg} / \mathrm{L}$} & \multicolumn{3}{|c|}{$300 \mathrm{mg} / \mathrm{L}$} \\
\hline & & 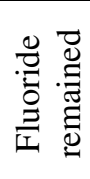 & 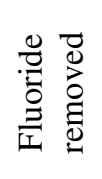 & $\begin{array}{l}\pi \\
0 \\
0 \\
0 \\
0 \\
0 \\
0\end{array}$ & 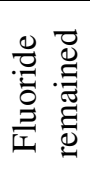 & 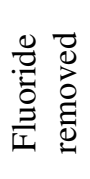 & $\begin{array}{l}\overline{7} \\
2 \\
0 \\
0 \\
0 \\
0 \\
0\end{array}$ & 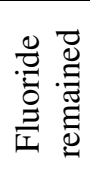 & 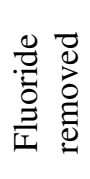 & $\begin{array}{l}\bar{\pi} \\
2 \\
0 \\
0 \\
0 \\
0 \\
0\end{array}$ \\
\hline 1 & 0.5 & 7.2 & 2.8 & 28 & 606 & 3.4 & 34 & 5.9 & 4.1 & 41 \\
\hline 2 & 1.0 & 6.5 & 3.5 & 35 & 6.0 & 4.0 & 40 & 5.5 & 4.5 & 45 \\
\hline 3 & 1.5 & 6.0 & 4.0 & 40 & 5.4 & 4.6 & 46 & 4.0 & 6.0 & 60 \\
\hline 4 & 2.0 & 5.1 & 4.9 & 49 & 4.3 & 5.7 & 57 & 3.9 & 6.1 & 61 \\
\hline 5 & 2.5 & 4.3 & 5.7 & 57 & 3.9 & 6.1 & 61 & 3.7 & 6.3 & 63 \\
\hline 6 & 3.0 & 3.9 & 6.1 & 61 & 3.5 & 6.5 & 65 & 3.5 & 6.5 & 65 \\
\hline 7 & 3.5 & 3.5 & 6.5 & 65 & 3.2 & 6.8 & 68 & 3.3 & 6.7 & 67 \\
\hline 8 & 4.0 & 3.3 & 6.7 & 67 & 3.2 & 6.8 & 68 & 2.7 & 7.3 & 73 \\
\hline
\end{tabular}

\section{Conclusion}

The defluoridation from the aqueous solutions using low cost adsorbent (i.e., alum) has been carried out in batch experiments. The fluoride water samples were prepared with the known concentration of 2, 4, 6, 8 and $10 \mathrm{mg} / \mathrm{L}$. Each fluoride concentration was tested with 100 , 200 and $300 \mathrm{mg} / \mathrm{L}$ of alum. The removal of fluorides by the defluoridating agent was studied up to 4 hours for all the fluoride concentrations. The variations in the percentage removal and attainment of equilibrium were recorded. The higher concentrations of defluoridating agents proved effective in reducing the fluoride concentration in the water samples to the extent of $70 \%$. In the lower concentrations of fluoride in water, $60 \%$ removal was recorded in the concentrations of defluoridating agent. Even at $60 \%$ removal, the left over fluorides were within the permissible limit for drinking water. All the concentrations of defluoridating agents have successfully reduced the fluoride content in waters to permissible limits. Based on the above said description, alum adsorbent could be used to remove fluoride selectively from aqueous solutions.

\section{Acknowledgement}

The authors gratefully acknowledge Prof. Z. Vishnuvarthan, BOS, Head of the Department of Environmental Sciences, Acharya Nagarjuna University, India for his fruitful scientific suggestions and discussions.

\section{References}

1. Srimurali M, Pragathi A and Karthikeyan J, Environ Pollut., 1998, 99(2), 285-289.

2. Fan X, Parker D J and Smith M D, Water Res., 2003, 37(2), 4929-4937.

3. Ghorai S and Pant K K, Chem Eng J., 2004, 98(1-2), 165-173.

4. Huang J C and Liu J C, Water Res., 1999, 33(16), 3403-3412.

5. Aldaco Irabien R, Irabien A and Luis P, Chem Eng J., 2005, (1071-3),113-117. 
6. Lounici H, Addour L, Belhocine D Grid H, Nicolas S, Bariou B and Mameri N, Desalination, 1997, 114(3), 241-251.

7. David C and Herbert M C, Desalination, 1998, 117(3), 19-35.

8. Kettunen R and Keskitalo P, Desalination, 2000, 131(1-3), 271-283.

9. Li Y H, Shuguang W, Anyuan C, Dan Z, Xianfeng Z, Cailu X, Zhaokun L, Dianbo R, Ji L, Dehai W and Bingqing W, Chem Phys Lett., 2001, 350(5-6), 412-416.

10. Li Y H, Shuguang W, Anyuan C, Dan Z, Xianfeng Z, Cailu X, Zhaokun L, Dianbo, R, Liang L, Dehai W, Bingqing W, Mater Res Bull., 2003, 38(3), 469-476.

11. Garmes H, Persinb F G, Sandeauxb J, Pourcellyb G and Mountadar M, Desalination, 2002, 145(1-3), 287-291

12. Hu C Y, Lo S L and Kuan W H, J Colloid Interface Sci., 2005, 283(2), 472-476

13. Bhargava D S and Killedar D.J, Water Res., 1991, 26(6), 781-788.

14. Christoffesen J, Christoffersen M R, Larsen R and Møller I J, Water Res., 1991, 25(2), 227-229.

15. Das D P, Jasobanta D and Parida K M, J Colloid Interface Sci., 2003, 261(2), 213-220.

16. National Environmental Engineering Research Institute (NEERI), Guidance manual for drinking water quality monitoring and assessment - A document by NEERI and NICD, 1998.

17. Harmon J A and Haleohmen S G, J Am Water Works Assoc., 1965, 57, 245-254.

18. Sorg T J, J Am Water Works Assoc., 1978, 70, 105-112.

19. Wright $\mathrm{T}$ and Nebel J, Environmental Science - Towards a Sustainable Future. Prentice-Hall of India Private Limited, New Delhi, 2002,

20. Sinha A K and Musturia Yashoda, Indian J Environ Sci., 2004, 8(2), 103-107. 